\title{
Correction to: Depletion of nuclear import protein karyopherin alpha 7 (KPNA7) induces mitotic defects and deformation of nuclei in cancer cells
}

Elisa M. Vuorinen ${ }^{1 \dagger}$, Nina K. Rajala ${ }^{1 \dagger}$, Teemu O. Ihalainen ${ }^{1,2,3}$ and Anne Kallioniemi ${ }^{1,4^{*}}$

\section{Correction to: BMC Cancer (2018) 18:325 https://doi.org/10.1186/s12885-018- 4261-5}

Following publication of the original article [1], the authors notified us that the Additional file 1 contains reviewer comments instead of the Supplementary tables. Supplementary tables are now provided in the Addtional file 1:

\section{Additional file}

Additional file 1: Table S1. Sequences of the $\mathrm{QPCR}$ primers used in this study. Table S2. Cell numbers per well used in this study for cell proliferation, cell cycle and immunofluorescent assays. Table S3. KPNA7 silencing efficiencies of the cell lines used in Fig. $124 \mathrm{~h}$ after siRNA treatment. (DOCX $17 \mathrm{~kb}$ )

\begin{abstract}
Author details
${ }^{1}$ BioMediTech Institute and Faculty of Medicine and Life Sciences, University of Tampere, 100, 33014 Tampere, PL, Finland. ${ }^{2}$ BioMediTech Institute and Faculty of Biomedical Sciences and Engineering, Tampere University of Technology, University of Tampere, 100, 33014 Tampere, PL, Finland.

${ }^{3}$ Tampere Imaging Facility, BioMediTech Institute and Faculty of Medicine and Life Sciences, University of Tampere, 100, 33014 Tampere, PL, Finland.

${ }^{4}$ Fimlab Laboratories, Biokatu 4, 33520 Tampere, Finland.
\end{abstract}

Received: 20 December 2018 Accepted: 20 December 2018

Published online: 14 January 2019

\section{Reference}

1. Vuorinen et al. (2018) Depletion of nuclear import protein karyopherin alpha 7 (KPNA7) induces mitotic defects and deformation of nuclei in cancer cells (2018) 18:325. https://doi.org/10.1186/s12885-018-4261-5

\footnotetext{
* Correspondence: anne.kallioniemi@tuni.fi

†Elisa M. Vuorinen and Nina K. Rajala contributed equally to this work.

${ }^{1}$ BioMediTech Institute and Faculty of Medicine and Life Sciences, University of Tampere, 100, 33014 Tampere, PL, Finland

${ }^{4}$ Fimlab Laboratories, Biokatu 4, 33520 Tampere, Finland

Full list of author information is available at the end of the article
}

(c) The Author(s). 2019 Open Access This article is distributed under the terms of the Creative Commons Attribution 4.0 International License (http://creativecommons.org/licenses/by/4.0/), which permits unrestricted use, distribution, and reproduction in any medium, provided you give appropriate credit to the original author(s) and the source, provide a link to the Creative Commons license, and indicate if changes were made. The Creative Commons Public Domain Dedication waiver (http://creativecommons.org/publicdomain/zero/1.0/) applies to the data made available in this article, unless otherwise stated. 